依 頼 論 文

第 120 回記念学術大会/ジョイントシンポジウム 1

$\lceil\mathrm{CAD} / \mathrm{CAM}$ から Digital Dentistry ヘーコンピュータを応用した歯科治療の最前線一」

\author{
デジタル時代のオールセラミックレストレーション \\ 中村 隆志
}

\title{
All Ceramic Restoration in the Digital Age
}

Takashi Nakamura, DDS, PhD

\begin{abstract}
抄 録
オールセラミックレストレーションが臨床で数多く用いられるようになった．以前は，セラミックスの 加工には煩雑な技工操作が必要であったが，CAD/CAM システムの導入後は，セラミックスの技工が大 幅に機械化された。ジルコニアをはじめとする高強度のセラミックス材料が開発されたこともオールセラ ミックレストレーションの普及を促進している，また，最近では歯科でもデジタル化が進み，セラミック スを加工する CAD/CAM システムだけでなく， 口腔内の印象採得にも CCD カメを使用するデジタル 印象が導入された。そこで本稿では, デジタル化が進んだオールセラミックレストレーションの概要と支 台歯形成，さらに口腔内スキャナーを用いて行うデジタル印象について解説する.
\end{abstract}

和文キーワード

セラミックス, デジタル，CAD/CAM，ジルコニア，口腔内スキャナー

\section{I 。はじめに}

1990 年代にセラミックスを加圧成形により加工する システムが登場し, 審美性や生体親和性に優れたオール セラミックレストレーションが臨床で普及するように なった。 ところが，このような材料は基本的にガラスセ ラミックスであり, 天然歯に近い色調や透過性を再現で きる半面, 煩雑で長時間を要する技工操作に加え, 強度 不足で臼歯部ブリッジには使用できないといった問題点 があった。

21 世紀になり，七ラミックスの加工に CAD/CAM システムが応用されるようになると煩雑なセラミックス の技工が大幅に省力化された。 セラミックスとしてはき わめて高い強度と䩡性をもち，臼歯部クラウン・ブリッ ジのフレームに応用できるジルコニアが登場したのも， $\mathrm{CAD} / \mathrm{CAM}$ システムのおかげである。 CAD/CAM シス テムでジルコニアを加工すれば，単冠やブリッジを同じ 材料で製作できるため，適用範囲や生産性が大幅に向上 した(図 1)。

歯科用 $\mathrm{CAD} / \mathrm{CAM}$ システムでは，作業用の模型を
レーザ計測して，CAD により修復装置の設計を行い CAM によりセラミックスの加工を行う方法が一般的で ある。従来は，各メーカーがそれぞれ独自のスキャナー と CAD ソフトを使用していた。ところが, 最近では種々 のシステムに使用することができる CAD ソフトを備え た汎用のスキャナーが一般になってきた。 さらに，シリ コーンなどの印象材を使用して行う印象採得にかわり, 口腔内に CCD カメラを備えたスキャナーを挿入して行 う新しいデジタル印象法が開発された。

本稿では，デジタル化が進んだオールセラミックレス トレーションについて解説し, あわせて, 口腔内スキャ ナーを用いたデジタル印象についても述べていきたい.

\section{II．臨床ステップと支台歯形成}

$\mathrm{CAD} / \mathrm{CAM}$ セラミックレストレーションでは, チェ アサイドで歯科医が支台歯形成および印象採得を行った のち，ラボサイドで作業用模型製作，スキャナーによる 模型計測, CAD によるデザイン決定, CAM によるセ ラミックスの切削加工の順に作業が進められるのが一般 的である (図 2). 最終的な色調再現は歯科技工士が行 


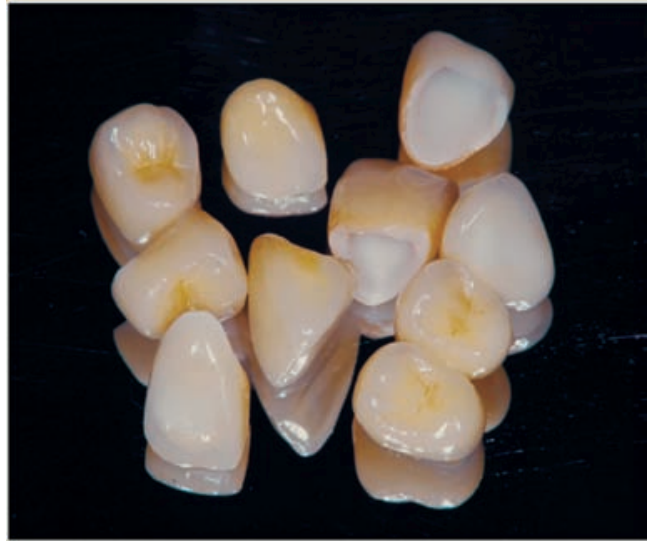

図 1 All-ceramic crowns and fixed-partial dentures with zirconia frames

By using zirconia frames, it became possible to fabricate the molar fixed partial dentures without the metal.

ジルコニアフレームを使用したクラウンとブリッジ 金属なしでも白歯部ブリッジが製作できるように なった。

い，完成した補経装置の調整や装着は口腔内で歯科医が 行う。このようにデジタル化が進んでも，すべてが機械 化されるわけではなく，歯科医や歯科技工士による作業 が不可欠であり，重要な意味をもっている.

臨床における最初のステップは支台歯形成である。形 成そのものは，手作業で補綴装置を作っていた時代と本 質的に変わりない. しかしながら, CAD/CAM システ ムでは，スキャナーにより支台歯形態をスキャンしなけ ればならないことや，ミリングマシンでセラミックスを 切削加工しなければならないことを考慮に入れて，支台 歯形成を行わなければならない. 現在の主流であるジル コニアコーピングであっても，CAD/CAM により製作 された製品がそのまま使えるわけではなく，多くの場合 は歯科技工士によるコーピング内面の調整が必要であ る。このような調整を最小限にするためにも，支台歯形 成は重要である.

クラウンの標準的な支台歯形態は, 従来のオールセラ ミッククラウンと同様である（図 3)。ただしこの支台 歯形態は失活歯を対象としたものであり, 生活歯では露 髄を避けるように形成を行わなければならない. 若年者 の前歯では，歯の表面から歯髄までの距離が $1.5 \mathrm{~mm}$ 以下になることがあり ${ }^{1)}$, 特に注意が必要である.また, 現在使用されているスキャナーは，ほとんどが非接触式 のレーザ計測を行うものであり, 計測のエラーを減少さ せるために，できるだけ滑らかな面に仕上げ，辺緑に遊 離エナメルが残らないようにしなければならない。レー ザ計測が困難な維持溝やピンホールは付与できない，辺
縁の形態は，良好な適合が得られるラウンデッドショル ダーあるいはシャンファーが使用される，支台歯のテー パーは，あまり小さくなると浮き上がりや適合不良につ ながるため, $12^{\circ}$ 程度が望ましい ${ }^{2)}$. セラミックスはミ リングマシンにより切削加工されるので, 使用する工具 の直径よりも細い部分は加工できない。 工具の直径は約 $1 \mathrm{~mm}$ ののが一般的であるので, 前歯の切縁や臼歯 の咬頭などに鋭縁が残らないように形成を行う必要があ る (図 4). 最近では, オールセラミックレストレーシ ヨン専用のバーセットも市販されているので, このよう なバーを使用すると，支台歯形成が容易に行える.

\section{III. セラミックス材料の分類と適応}

$\mathrm{CAD} / \mathrm{CAM}$ セラミックレストレーションに使用する 材料は, ガラスセラミックス, ガラス浸潤セラミックス, 酸化物セラミックスの 3 種に大別される (表 1)。ガラ スセラミックスは透過性に優れるが，強度や䩲性はそれ ほど大きくない，そのため，インレーやべニア，前歯ク ラウンには適した材料であるが， 臼歯部のクラウン・ブ リッジのフレームには使用できない. ガラスセラミック スだけでクラウンやべニアを製作する場合は，修復装置 が支台歯の色調に影響を受けることを忘れてはならな い. また，ガラスセラミックスは，メタルや酸化物セラ ミックスフレームの前装材料としても用いられる. ガラ ス浸潤セラミックスは結晶間隙をガラスで埋めることに より物性を向上させた材料であるが，酸化物セラミック スほど強度が高くないので現在ではあまり使用されてい ない. 一方, ジルコニアに代表される酸化物セラミック スは，きわめて高い強度や勒性ももち，臼歯部ブリッジ のフレームにも使用できる.

実際の臨床では，このようなセラミックス材料の特徵 を理解して使い分けをすることが重要となる (図 5). すなわち，生活歯やレジンコアなど支台歯に変色がない 前歯や小臼歯ではガラスセラミックスが使用可能であ り, 支台歯に変色がある場合や大臼歯のクラウン・ブリ ッジにはジルコニアが適している。また，臼歯部では従 来の陶材焼付鋳造冠も有効である.

ジルコニアは前歯の単冠から臼歯のブリッジまで, 幅 広く適応できるが，すべてのジルコニアが全く同じ性質 をもつわけではない. 現在, 国産のジルコニアシステム として, Aadva ${ }^{\mathrm{TM}}$ (株式会社ジーシー, 東京, 日本), Katana（株式会社ノリタケデンタルサプライ, 愛知, 日本), NanoZR (パナソニックデンタル株式会社, 大 阪，日本) の 3 種が主に使用されているが，やはり各々 のシステムは異なる特徵をもつ（表 2). Aadva ${ }^{\mathrm{TM}}$ と 


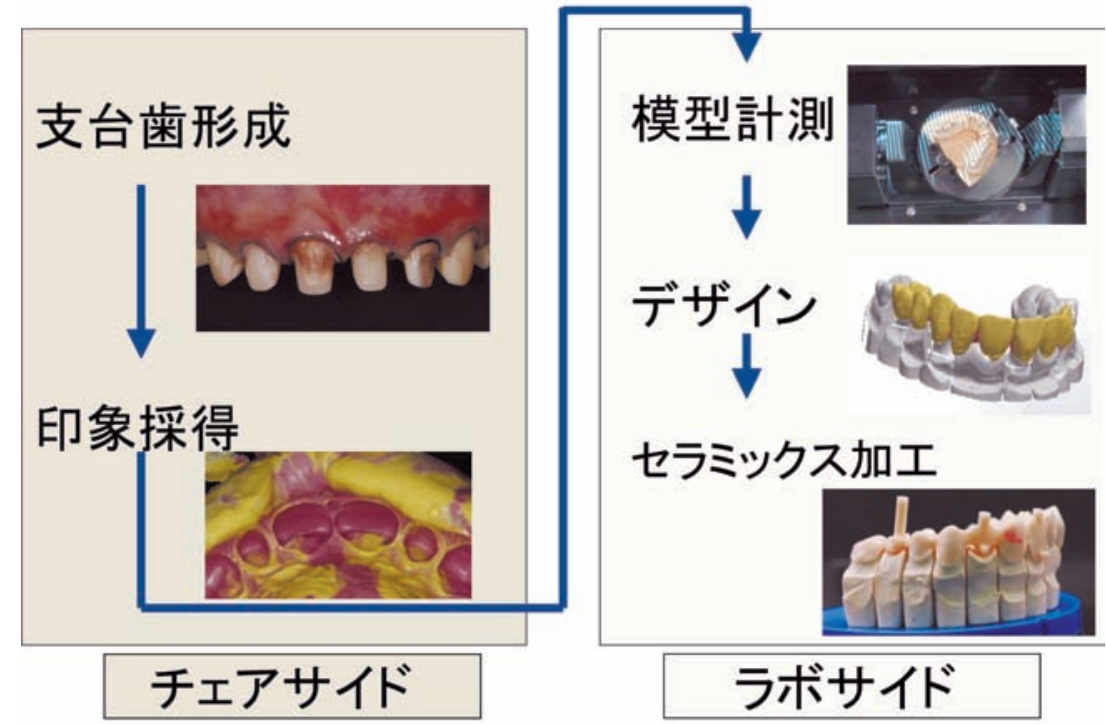

図 2 Clinical steps of CAD/CAM all-ceramic restorations Productivity on the lab side has been greatly improved by CAD/CAM technology. オールセラミックレストレーションの臨床ステップ

CAD/CAM の導入によりラボサイドの生産性が大幅に向上した。

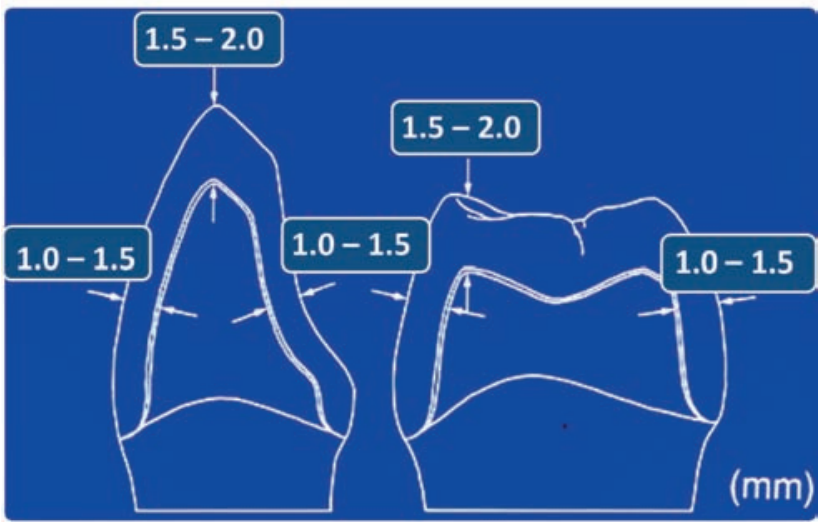

図 3 The standard abutment tooth form of an allceramic crown

The amount of reduction decreases in the vital tooth to prevent pulp exposure.

オールセラミッククラウンの標準的な支台歯形態 生活歯では露䯣を防ぐため形成量が少なくなる。

Katana は，ジルコニアとしては最も一般的なイットリ ア系の材料であり，わずかに透過性をもっている。

NanoZR は，他の材料とは異なり純粋なジルコニアで はなく，セリア系ジルコニアとアルミナのコンポジット 材料である. NanoZR は，一般的なイットリア系のジ ルコニアよりも強度や勒性が高く, 低温劣化しにくい性 質をもっているが, 光の透過性はほとんどない. 3 種の システムともにオープンタイプのスキャナーと CAD (3 Shape, コペンハーゲン，デンマーク）を採用して いる(図 6)。3 Shape 社製のスキャナーは，各メーカー
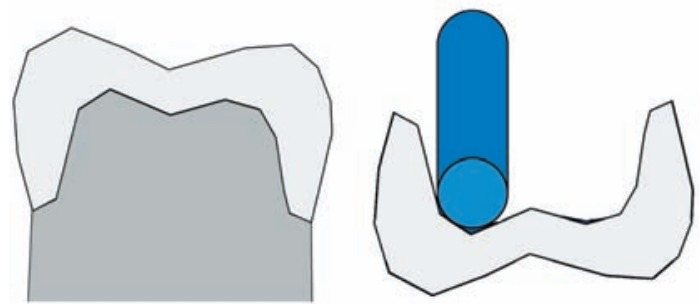

図 4 When the sharpness remains in the cutting edge of the incisor or in the cusp tip of the molar, it is not possible to process it with the milling machine 前歯の切縁や臼歯の咬頭頂などに鋭縁が残るとミリ ングマシンによる加工ができない

に OEM で供給されており，基本的に同じ CAD と考え て良い。最近では，スキャナーやCADが淘汰され， 3 Shape や Dental Wings (モントリオール, カナダ) のようなオープンタイプのものが数多く用いられてい る. CAD によりジルコニアフレームの設計が終わると (図 7)，デー夕を各メーカーの CAM に送り，ミリング マシンによりフレームを切削する. Aadva ${ }^{\mathrm{TM}}$ や Katana では，半焼結あるいは未焼結の軟らかいブロックを切削 加工した後に， $1,400 \sim 1,600^{\circ} \mathrm{C}$ で最終焼結してジルコ ニアフレームが完成する，焼結の際に約 20\% 収縮する のでここを $\mathrm{CAD}$ により補正したデー夕に基づいて CAM による加工が行われる，NanoZR は，完全焼結 したきわめて固いブロックを切削加工するので，切削は 困難であるが，加工後の寸法変化はない，いずれのジル コニアシステムでもフレームが完成した後で，歯科技工 
表 1 Characteristics of ceramic materials for CAD/CAM restorations

Generally, as the materials with relatively high strength and fracture toughness have not good translucency, these materials are used as frames.

$\mathrm{CAD} / \mathrm{CAM}$ に使用するセラミックス材料の特徵

一般に強度や䩡性の高い材料は透過性が低く, 主にコーピングに使用される。

\begin{tabular}{|c|c|c|c|}
\hline & $\begin{array}{l}\text { ガラス } \\
\text { セラミックス }\end{array}$ & $\begin{array}{l}\text { ガラス浸潤 } \\
\text { セラミックス }\end{array}$ & $\begin{array}{l}\text { 酸化物 } \\
\text { セラミックス }\end{array}$ \\
\hline 成形法 & $\begin{array}{l}\text { 築盛, プレス } \\
\mathrm{CAD} / \mathrm{CAM}\end{array}$ & $\begin{array}{l}\text { 耐火模型 } \\
\text { CAD/CAM }\end{array}$ & $\mathrm{CAD} / \mathrm{CAM}$ \\
\hline 強度 (MPa) & $100 \sim 200$ & $200 \sim 500$ & $\begin{array}{l}500 \quad(\text { アルミナ） } \\
1,000 \quad(\text { ジルコニア })\end{array}$ \\
\hline 透過性 & 高い & 低い & 低い \\
\hline 適 応 & $\begin{array}{l}\text { 前装材料, インレー, ベ } \\
\text { ニア, 単冠 (前歯・小臼 } \\
\text { 歯) }\end{array}$ & $\begin{array}{l}\text { コーピング } \\
\text { (単冠) } \\
\text { (前歯ブリッジ) }\end{array}$ & $\begin{array}{l}\text { コーピング } \\
\text { (単冠) } \\
\text { (前臼歯ブリッジ) }\end{array}$ \\
\hline 製 品 & $\begin{array}{l}\text { Empress } 2 \\
\text { e.max } \\
\text { Dicor etc }\end{array}$ & $\begin{array}{l}\text { In-Ceram } \\
\text { Alumina } \\
\text { Spinell } \\
\text { Zirconia }\end{array}$ & $\begin{array}{l}\text { アルミナ } \\
\text { Procera AllCeram } \\
\text { ジルコニア } \\
\text { Lava, Everest, } \\
\text { Cercon, Katana etc }\end{array}$ \\
\hline
\end{tabular}

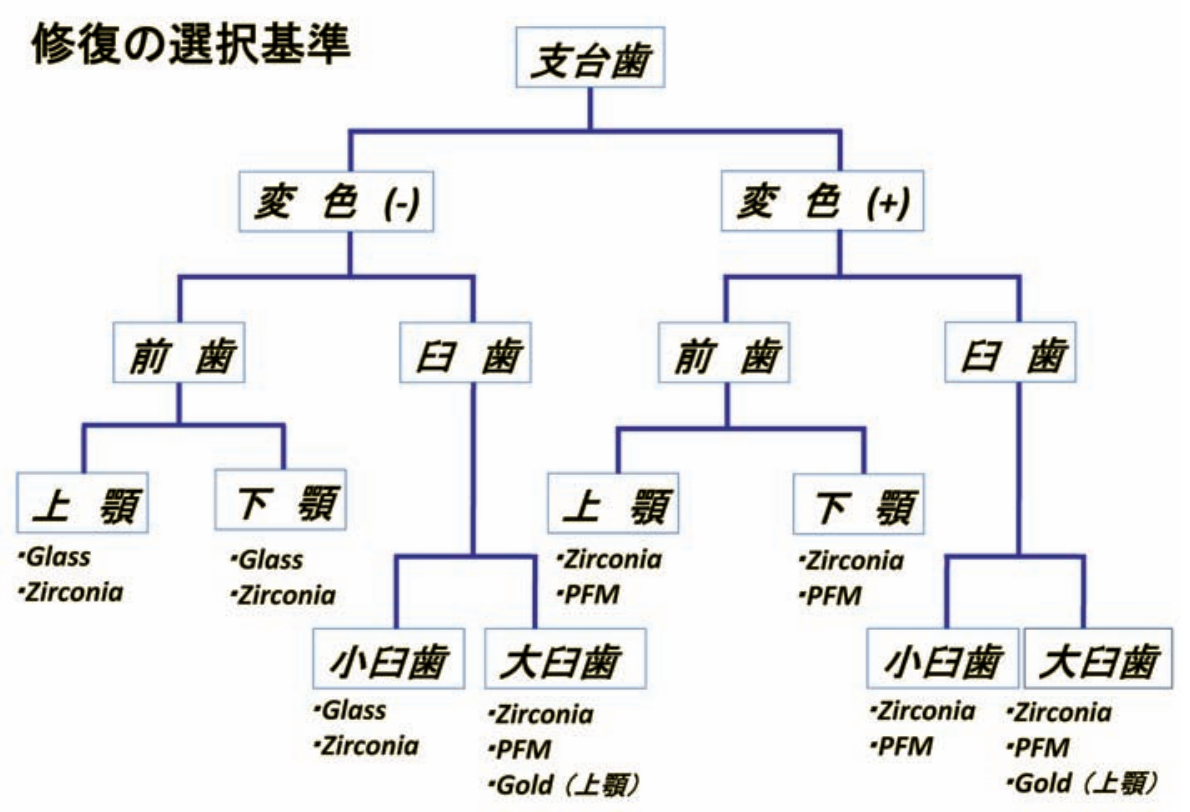

図 5 Selection criterion of ceramic restoration

The presence of the discoloration of the abutment tooth becomes a standard. In the molar region, PFM (porcelain fused to metal) crown or Gold crown (only for the upper molar) also becomes one of the choices.

セラミック修復の選択基準

支台歯の変色の有無が基準となる。臼歯部では, PFM (陶材焼付鋳造冠) や Gold (ゴールドクラウン，上顎のみ）も選択肢の一つとなる. 
表 2 Characteristics of domestic zirconia systems

The same type of scanner (3 Shape) is used for these systems.

国産のジルコニアシステムの特徵

いずれも 3 Shape のスキャナーを使用する.

\begin{tabular}{|c|c|c|c|c|c|}
\hline & $\begin{array}{c}\text { スキャナー・ } \\
\text { CAD }\end{array}$ & 組 成 & 切削用ブロック & 強度・靶性 & 透過性 \\
\hline $\begin{array}{l}\operatorname{Aadva}^{\mathrm{TM}} \\
(\text { ジーシー) }\end{array}$ & 3 Shape/自社 & $\begin{array}{l}\text { イットリア系 } \\
\text { ジルコニア }\end{array}$ & 半焼結 & 0 & $\triangle$ \\
\hline $\begin{array}{l}\text { Katana } \\
\text { (ノリタケ) }\end{array}$ & 3 Shape & $\begin{array}{l}\text { イットリア系 } \\
\text { ジルコニア }\end{array}$ & 未焼結 & 0 & $\triangle$ \\
\hline $\begin{array}{l}\text { NanoZR } \\
\text { (パナソニック) }\end{array}$ & 3 Shape & 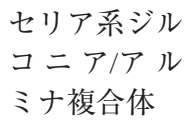 & 完全焼結 & (a) & $\times$ \\
\hline
\end{tabular}

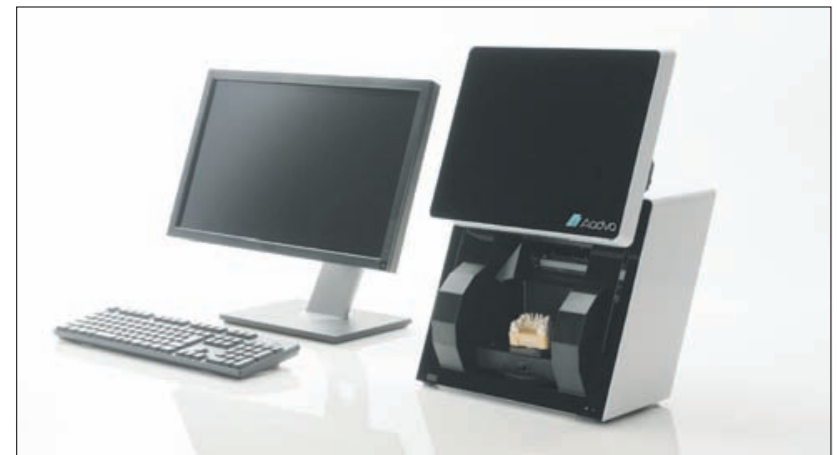

図 6 A typical open-type scanner by 3 Shape All of three domestic zirconia systems use this type of scanner (quotation from the information material of GC).

代表的なオープンタイプのスキャナー (3 Shape) 国産の 3 社はいずれもこのスキャナーを採用してい る(ジーシー社資料より引用).

士が歯冠色陶材を用いて色調と形態の再現を行う。ワッ クスアップをしてから，ガラスセラミックスをプレスに より加工する方法もあるが，日本では粉末の陶材を築 盛，焼成する方法が一般的である。

\section{IV. 新しい口腔内スキャナーの登場}

1987 年に世界で最初に歯科に導入された CAD/ CAM(Cerec 1, Siemens, ベンスハイム, ドイツ)は, 口腔内に CCD カメラを挿入して，支台歯および隣在歯 の形態を光学的にスキャンするシステムであった。しか しながら，このシステム以降に登場した CAD/CAM は ほとんどが作業用模型を対象とするものであり，口腔内 で光学的にデジタル印象する方法は Cerec に限られた ものであった．ところが，数年前に歯列全体をデジタル 印象できる口腔内スキャナーが登場して状況は大きく変 わりつつある(図 8).

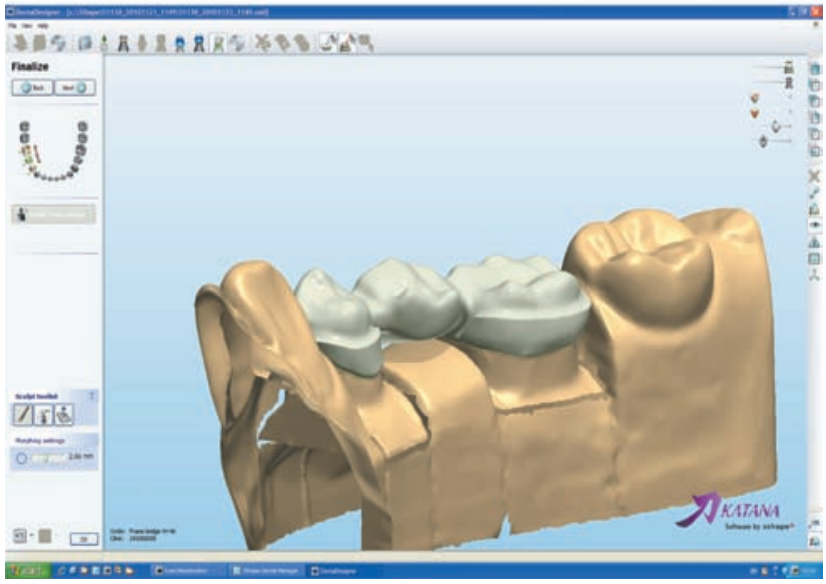

図 7 In case of the open-type scanner, it is quite easy to design the zirconia frames (quotation from the information material of Noritake Dental Supply) オープンタイプのスキャナーでは，フレームの設計 が容易である（ノリタケデンタルサプライ社資料よ り引用)。

最近の口腔内スキャナーは，CCD カメラを備えた部 分を口腔内に挿入し，静止画あるいは動画を撮影して歯 列の形態をデジタル化してとらえる構造となっている. 適応は，単冠あるいはブリッジで，セラミックスだけで なく鋳造のメタルや陶材焼付にも対応できる ${ }^{3)}$. 作業用 模型が必要な場合は，光造形あるいはミリングにより模 型を製作する (図 9).

印象材を使う従来の印象と比較すると，所要時間が片 顎 2３ 分と短く，患者の負担が小さいこと，印象材が 不要であること，画面上で印象を確認しながら作業を行 えること，ラボへのデータ転送が瞬時に行え，模型では なくデジタルデータで保存が可能であることなどが利点 である (表 3)。その半面，歯列の上方からカメラで撮 影するので，歯肉縁下の印象は行いにくいことや，信頼 性や精度は従来の印象ほど高くないことが現時点では問 


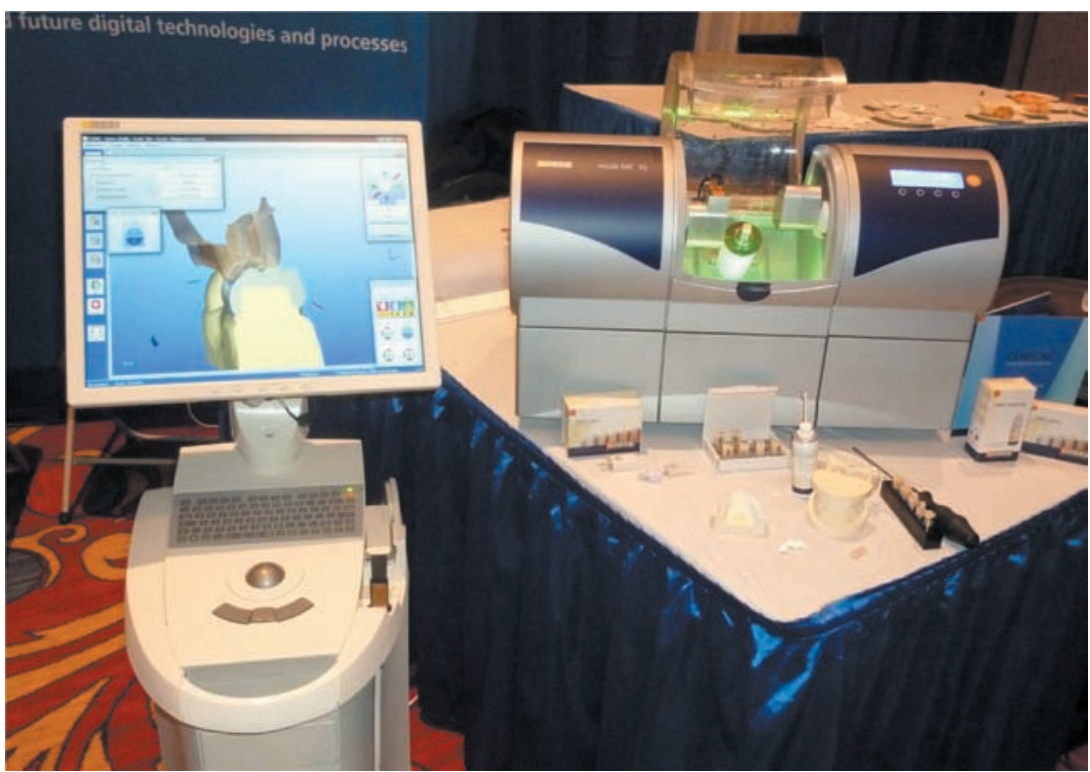

図 8 An intra-oral scanner and a milling machine (Cerec AC, Sirona, Bensheim, Germany) To take a digital impression, a hand-piece with CCD cameras is put into the mouth. 口腔内スキャナーとミリングマシン（Cerec AC，Sirona，ベンスハイム，ドイツ） CCD カメラを備えたハンドピースを口腔内に入れて歯列のデジタル印象を行う.

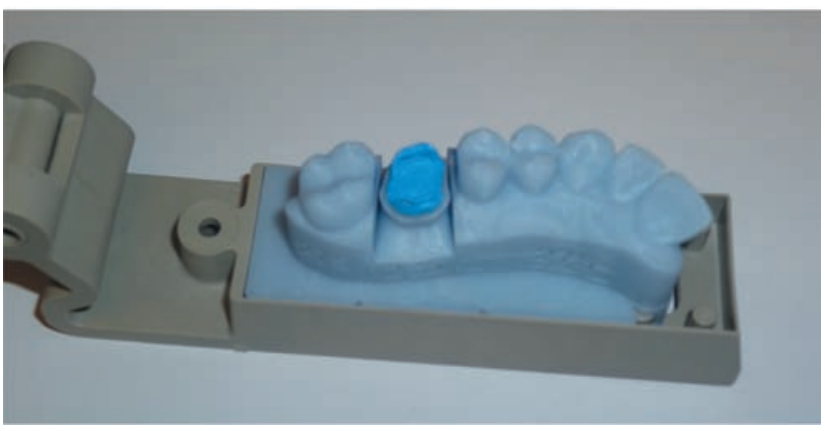

図 9 Working model produced by light forming In case of the digital impression, working models made by an optical forming or by milling are used instead of gypsum models. 光造形により製作した作業用模型

口腔内スキャナーでは石膏模型は使用せず光造形や ミリングにより模型を製作する。

題であろう。欧米ではすでに数多くの口腔内スキャナー が発表され，日本でも2011 年に正式導入されたので, 今後はこのような口腔内スキャナーが普及することが予 想される。

\section{V. おわりに}

診断から治療まで，歯科のさまざまな分野でデジタル 化が進んでいる。 なかでもオールセラミックレストレー ションはデジタル化の恩恵を大きく受けた修復であると
表 3 Comparison between conventional and digital impression 従来型印象法と光学印象の比較

\begin{tabular}{lcc}
\hline & 従来型印象 & デジタル印象 \\
\hline 所用時間 & 片顎 10 分 & 片顎 2 3 分 \\
印象の確認 & や困難 & 容易（画面上） \\
技工指示書 & 手書き & 画面上で設定 \\
ラボへの輸送 & $1 \sim 2$ 日 & 即時 \\
作業用模型 & 石膏 & SLA/ミリング \\
模型保存 & 石膏模型 & デジタルデータ \\
歯肉縁下印象 & やや困難 & 困難 \\
信頼性 & 高い & まだ高くない \\
\hline
\end{tabular}

いえる，今では，セラミックスのクラウン・ブリッジは 大多数がその製作ステップに $\mathrm{CAD} / \mathrm{CAM}$ システムを応 用している。患者にとって負担となる印象採得にも，口 腔内スキャナーが登場したことで，大きな変化が訪れよ うとしている。ささらに，CAD/CAM システムや口腔内 スキャナー以外に，コンピュータを応用した測色システ ムもオールセラミックレストレーションにおける色調再 現に大きく貢献している.

このようなデジタル化は歯科臨床にとって非常に有効 なものであり，生産性の向上や負担の減少は，結果とし て患者の利益にもつながる。しかしながら，デジタル化 は，歯科医や歯科技工士の技術を向上させるものではな い，正確な診断のもとで行われる補綴装置の選択や支台 
歯形成，審美性だけでなく機能を考慮した色調や形態再 現，適切な咬合調整など，歯科医や歯科技工士のテクニ ックが重要であることを忘れてはならない.

\section{謝辞}

本稿の執筆にあたり宮前守寬先生（大阪府開業）および， ジーシー，スリーエムヘルスケア，ノリタケデンタルサプラ イ，パナソニックデンタルの各社に協力をいただきました。 深く感謝いたします。

\section{文献}

1）大橋康良. 架工義歯の前歯支台装置に関する研究 : 第 2 編＼cjkstart各支台装置の検討。歯科学報 1968;68: 726-766.

2) Beuer F, Aggstaller H, Richter J, Edelhoff D, Gernet W.
Influence of preparation angle on marginal and internal fit of CAD/CAM-fabricated zirconia crown copings. Quintessence Int 2009; 40: 243-250.

3) Syrec A, Reich G, Ranftl D, Klein C, Cerny B, Brodesser J. Clinical evaluation of all-ceramic crowns fabricated from intraoral digital impressions based on the principle of active wavefront sampling. J Dent 2010; 38: 553-559.

著者連絡先：中村 隆志

=565-0871 大阪府吹田市山田丘 1-8

Tel: 06-6879-2946

Fax: 06-6879-2947

E-mail:tnakamur@dent.osaka-u.ac.jp 


\section{All Ceramic Restoration in the Digital Age}

Takashi Nakamura, DDS, PhD

Department of Fixed Prosthodontics, Osaka University Graduate School of Dentistry

Ann Jpn Prosthodont Soc 4: 132-139, 2012

\section{ABSTRACT}

A lot of all-ceramic restorations are now being used in clinical situations. After the dental CAD/CAM system was introduced, the laboratory procedures for ceramic forming became greatly mechanized. The development of high-strength ceramic materials, including zirconia, also promotes the spread of all-ceramic restorations. In these days, digital technology became popular in the field of dentistry, and a digital impression technique using CCD cameras was introduced as a substitute of a mechanical impression. The purpose of this paper is to explain the basics of all-ceramic restorations by using CAD/CAM and digital technology, and to introduce a digital impression technique using the intra-oral scanner.

\section{Key words}

ceramics, digital dentistry, CAD/CAM, zirconia, intra-oral scanner 